\title{
Erratum to: Interaction between Dioxane and Nanocluster Polyoxomolybdates and Their Composites Containing Water-Soluble Polymers
}

\author{
A. A. Ostroushko ${ }^{a, *}$, L. V. Adamova ${ }^{a}$, K. V. Grzhegorzhevskii ${ }^{a}$, and E. V. Koveza ${ }^{a}$ \\ ${ }^{a}$ Institute of Physics and Applied Mathematics, Yeltsin Ural Federal University, Yekaterinburg, 620002 Russia \\ *e-mail: alexander.ostroushko@urfu.ru \\ Received July 2, 2020; revised July 2, 2020; accepted July 2, 2020
}

DOI: $10.1134 / \mathrm{S} 0036024420120237$

Page 766, Table 1, limiting sorption values for methanol and acetone of $\mathrm{Mo}_{72} \mathrm{Fe}_{30}$ should read 6 and 2, respectively:

$\mathrm{Mo}_{72} \mathrm{Fe}_{30} \quad 6 /-1 \quad 0.5 /-0.3 \quad 2 /-0.5 \quad 3.5 /-4$

The original article can be found online at

https://doi.org/10.1134/S0036024420040159 